\title{
The restricted potential for recovery of growth plate chondrogenesis and longitudinal bone growth following exposure to pro-inflammatory cytokines
}

\author{
V E MacRae ${ }^{1,2}$, C Farquharson ${ }^{1}$ and S F Ahmed ${ }^{2}$ \\ ${ }^{1}$ Bone Biology Group, Division of Gene Function and Development, Roslin Institute, Edinburgh EH25 9PS, UK \\ ${ }^{2}$ Bone and Endocrine Research Group, Royal Hospital for Sick Children, Glasgow G3 8SJ, UK \\ (Requests for offprints should be addressed to V E MacRae; vicky.macrae@bbsrc.ac.uk)
}

\begin{abstract}
Childhood chronic inflammatory disease can be associated with transient and permanent growth retardation. This study examined the potential for spontaneous growth recovery following pro-inflammatory cytokine exposure. Murine ATDC5 chondrogenic cells and postnatal metatarsals were exposed to interleukin (IL)-1 $\beta$, IL-6 and tumour necrosis factor- $\alpha$ (TNF $\alpha)$, and their growth and proliferative capacity were determined following recovery. TNF $\alpha$ and IL-1 $\beta$ reduced chondrocyte proliferation and aggrecan and collagen types II and $\mathrm{X}$ expression at minimum concentrations of $10 \mathrm{ng} / \mathrm{ml}$ and $0.1 \mathrm{ng} / \mathrm{ml}$ respectively. TNF $\alpha$ but not IL-1 $\beta$ exposure led to increased caspase-3 activity and altered cellular morphology, consistent with reduced viability. Cytokine exposure particularly inhibited proteoglycan synthesis. This effect was dose and duration dependent. Compared with the control, IL- $1 \beta$ and TNF $\alpha$ led to a $71 \%$ and $45 \%$ reduction in metatarsal growth after 8 days of exposure
\end{abstract}

respectively $(P<0 \cdot 05)$. An additive effect of IL-1 $\beta$ combined with TNF $\alpha$ was observed $(110 \%$ decrease; $P<0 \cdot 05)$. Metatarsals exposed to IL-1 $\beta$ or TNF $\alpha$ individually for a 2-day period, and allowed to recover spontaneously in the absence of cytokines for a further 6 days, showed normal growth trajectories. In combination, growth was 59\% lower $(P<0 \cdot 01)$ compared with control metatarsals at the end of the recovery period. Exposure to the combination for 4 days followed by a 4-day recovery period resulted in $87 \%$ decrement compared with controls $(P<0 \cdot 05)$. IL-6 did not alter any parameter studied. IL- $1 \beta$ and TNF $\alpha$ exert diverse inhibitory effects on ATDC5 chondrocyte dynamics and metatarsal growth. The extent of recovery following cytokine exposure depends on the duration of exposure, and may be incomplete following longer periods of exposure.

Journal of Endocrinology (2006) 189, 319-328

\section{Introduction}

Adverse longitudinal growth in children with chronic inflammatory diseases is common, and can be attributed to a combination of systemic factors that include poor nutrition, excess glucocorticoids, sex steroid deficiency and defects in growth hormone $(\mathrm{GH})$ secretion and action (Farthing et al. 1981, Kirscher et al. 1981, Mainardi et al. 2002, Mushtaq \& Ahmed 2002). Although this may be a transient phenomenon that is dependent on the resolution of the above factors (Kirscher et al. 1981), there are some concerns that it may also result in permanent growth restriction (Sawczenko et al. 2003). Although cytokines may affect growth through systemic mechanisms that alter GH secretion (Mainardi et al. 2002), growth disorders in chronic inflammatory disease may also be due to a direct effect of cytokines at the level of the growth plate (de Hooge et al. 2003, Martensson et al. 2004).
The inhibitory effects of the pro-inflammatory cytokines interleukin (IL)- $1 \beta$, tumour necrosis factor- $\alpha$ $(\mathrm{TNF} \alpha)$ and IL-6 on articular chondrocyte growth dynamics are well recognised (Goldring 2003). However, the direct effects of these cytokines on growth plate chondrocytes are not clearly understood. Previous studies that have shown that IL-1 $\beta$ and TNF $\alpha$ inhibit growth plate chondrocyte differentiation and induce cell death (Kato et al. 1993, Aizawa et al. 2001). However, these studies have examined the effect of pro-inflammatory cytokines on primary growth plate chondrocytes and were, therefore, unable to examine the effect of cytokines on the different stages of the chondrocyte life cycle (Robson et al. 1998, Koedam et al. 2000). The rate of longitudinal bone growth is determined by a complex interplay of proliferative kinetics, size of the proliferative pool matrix synthesis and hypertrophic chondrocyte enlargement (Atsumi et al. 1990, Breur et al. 1991). 
The murine ATDC5 chondrocyte cell line has been shown to undergo the temporal sequence of events that occur during longitudinal bone growth in vivo and, thereby, provides an excellent model to study the molecular mechanisms underlying regulation of growth plate maturation and endochondral bone formation (Shukunami et al. 1997, Horiguchi et al. 2000, Farquharson 2003). The local effect of pro-inflammatory cytokines on the growth plate has also been studied in a fetal organ-culture model of bone growth, where it has been reported that they reduce proteoglycan synthesis and restrict longitudinal growth (van Bezooijen et al. 2002, Martensson et al. 2004). Given that there are clear differences between the prenatal and postnatal regulation of growth it would be beneficial to examine these effects in a postnatal model of bone growth. In addition, the potential for spontaneous recovery in chondrogenesis or longitudinal growth following cytokine exposure is, to date, unknown.

In this study, the ATDC5 cell line was used to characterise and compare the effects of IL- $1 \beta$, IL- 6 and TNF $\alpha$ on cell proliferation, differentiation and apoptosis. Explant studies were also undertaken to examine their effect on the longitudinal growth of neonatal murine metatarsals. Subsequently, these models were used to examine the potential for spontaneous recovery of chondrocyte dynamics and longitudinal growth following temporary exposure to the pro-inflammatory cytokines.

\section{Materials and Methods}

\section{Chondrocyte cell culture}

The ATDC5 chondrocyte cell line was sourced from the RIKEN cell bank (Ibaraki, Japan) and maintained as described by Atsumi et al. (1990). Cells were maintained in T175 tissue-culture flasks (Greiner Bio-One GmbH, Frickenhausen, Germany) at a density of 250000 cells/ flask in a maintenance medium of Dulbecco's modified Eagles' medium/Ham's F12 (Invitrogen) supplemented with $5 \%$ FCS (Invitrogen), $10 \mu \mathrm{g} / \mathrm{ml}$ human transferrin, $3 \times 10^{-8} \mathrm{M}$ sodium selenite (Sigma), sodium pyruvate

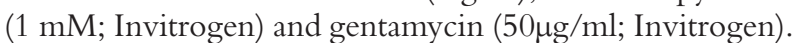
For individual experiments, semi-confluent cultures were passaged with trypsin-EDTA (Sigma) and cultured (day 0) at a density of 6000 cells $/ \mathrm{cm}^{2}$ in multi-well plates (Costar, High Wycombe, Bucks, UK) in a differentiation medium that consisted of maintenance medium supplemented with insulin $\left(10 \mu \mathrm{g} / \mathrm{ml}\right.$; Sigma). Incubation was at $37^{\circ} \mathrm{C}$ in a humidified atmosphere of $95 \%$ air $/ 5 \% \quad \mathrm{CO}_{2}$ and the medium was changed every second/third day. In all experiments, unless otherwise stated, cytokines were added to chondrocyte cultures from days 13 to 17 . During this period the cells express established markers of the chondrocyte differentiated phenotype (Mushtaq et al. 2002).
Chondrocyte number, proliferation, differentiation and matrix production Murine $\mathrm{TNF} \alpha$ (Autogen Bioclear, Calne, Wilts, UK), IL-1 $\beta$ (Autogen Bioclear) and IL-6 (Autogen Bioclear) (+IL-6 soluble receptor (IL-6R) at matching concentrations (R\&D Systems Europe Ltd, Abingdon, Oxon, UK)) were added to the cells at a final concentration of $100,10,1 \cdot 0$ and $0 \cdot 1 \mathrm{ng} / \mathrm{ml}$ and compared with control cultures, which received vehicle only. The cytokines were also added to cells in all available combinations at a final concentration of $10 \mathrm{ng} / \mathrm{ml}$. The rate of chondrocyte proliferation was assessed in cells cultured in 48-well plates over a $24-\mathrm{h}$ period starting on day 13 . On day 14 , the chondrocytes were incubated with $0 \cdot 2 \mu \mathrm{Ci} / \mathrm{ml}\left[{ }^{3} \mathrm{H}\right]$ thymidine $(37 \mathrm{MBq} /$ $\mathrm{ml}$; Amersham Pharmacia Biotech) for the last $2 \mathrm{~h}$ of the culture period. The amount of radioactivity incorporated into trichloroacetic acid-insoluble precipitates was measured (Farquharson et al. 1999). Cell protein content was assessed using a detergent compatible $\left(D_{C}\right)$ protein assay reagent (Bio-Rad Laboratories Inc) based on the Lowry procedure (Lowry et al. 1951) and lyophilised bovine plasma $\gamma$-globulin was used as standard (Bio-Rad Laboratories Inc). Proteoglycan synthesis was evaluated by staining cells with Alcian Blue (Shukunami et al. 1997, Mushtaq et al. 2002). Cells were cultured in 12-well plates, and exposed to the cytokines on day 13 and day 15. On day 17, the cells were washed twice with PBS, fixed in 95\% methanol for $20 \mathrm{~min}$ and stained with $1 \%$ Alcian Blue $8 \mathrm{GX}$ (Sigma) in $0.1 \mathrm{M} \mathrm{HCl}$ overnight and rinsed with distilled water. Alcian Blue-stained cultures were extracted with $1 \mathrm{ml} 6 \mathrm{M}$ guanidine- $\mathrm{HCl}$ for $6 \mathrm{~h}$ at room temperature. The optical density (O.D.) was determined at $630 \mathrm{~nm}$ using a spectrophotometer (Multiskan Ascent; Thermo Electron Corporation, Vantaa, Finland).

Analysis of chondrogenic gene expression On days 13 and 15, IL-6 (+IL-6R at matching concentrations), IL-1 $\beta$ and TNF $\alpha$ were added at a final concentration of $10 \mathrm{ng} / \mathrm{ml}$ to cells cultured in six-well plates. The experiment was stopped on day 17 and total RNA was extracted from chondrocytes by repeated aspiration through a 25 gauge syringe needle in $0.5 \mathrm{ml}$ Ultraspec (Biotecx, Houston, TX, USA). Following extraction with chloroform, RNA in the aqueous phase was precipitated with isopropanol and bound to RNA Tack resin (Biotecx) following the manufacturer's protocol. After washing with $75 \%$ ethanol, the RNA was eluted in $100 \mu$ l ribonuclease-free water (Houston et al. 1999). For each sample, total RNA content was assessed by absorbance at $260 \mathrm{~nm}$ and purity by A260/A280 ratios, which were $1 \cdot 9-2 \cdot 0$ in all cases. All preparations were diluted to a concentration of $50 \mathrm{ng} / \mu \mathrm{l}$ and stored at $-70{ }^{\circ} \mathrm{C}$. Gene expression was analysed by semi-quantitative RT-PCR (Jefferies et al. 1998, 2000, Farquharson et al. 1999, Houston et al. 1999). Aliquots of $500 \mathrm{ng}$ RNA (or an equivalent volume of water as a control) 
were reverse transcribed in $20 \mu \mathrm{l}$ reactions containing cDNA equivalent to $10 \mathrm{ng}$ RNA and $200 \mathrm{nM}$ genespecific primers in $11.1 \times$ PCR buffer (Jefferies et al. 1998). Primers for $18 \mathrm{~S}$ (20 cycles, 488 bp) (Ambion, Huntingdon, Cambs, UK); collagen type II (30 cycles, $172 \mathrm{bp}$, forward 5'-CAC ACT GGT AAG TGG GGC AAG ACC-3', reverse 5'-GGA TTG TGT TGT TTC AGG GTT CGGG-3'); collagen type $\mathrm{X}$ (35 cycles, $583 \mathrm{bp}$, forward 5'-AGG CAA GCC AGG CTA TGG AA-3', reverse 5'-GCT GTC CTG GAA AGC CGT TT-3'; aggrecan (35 cycles, 218 bp, forward 5'-CGA GAA TGA CAC CTG CTA GG-3', reverse 5'-AAG AAG ACA GGA CCA GGA AGG-3') were used. The cycling profile was $1 \mathrm{~min}$ at $92{ }^{\circ} \mathrm{C}$ (first cycle, $2 \mathrm{~min}$ ), $1 \mathrm{~min}$ at $55^{\circ} \mathrm{C}$ and $1 \mathrm{~min}$ at $70^{\circ} \mathrm{C}$. The number of cycles performed was carefully titrated to ensure that the reactions were in the exponential phase. Reaction products were analysed on $1.5 \%$ agarose gels in the presence of ethidium bromide $(250 \mu \mathrm{g} / \mathrm{l})$ and a digital image of each gel was captured using a gel documentation system (Bio-Rad Laboratories Inc).

Apoptosis Apoptosis of the cells was measured using a caspase-3 colorimetric assay (R\&D Systems) with spectrophotometric quantification at $405 \mathrm{~nm}$. TNF $\alpha$, IL-1 $\beta$ and IL-6 (+IL-6R) were added to the cells at a final concentration of $10 \mathrm{ng} / \mathrm{ml}$ and compared with control cultures. Apoptosis was assessed following the manufacturer's protocol in cells cultured in six-well plates over a $24-\mathrm{h}$ period starting on day 16.

Recovery experiments in ATDC5 ATDC5 cells were exposed to IL-1 $\beta$, TNF $\alpha$ and IL- $1 \beta+\mathrm{TNF} \alpha$ in combination $(10 \mathrm{ng} / \mathrm{ml})$ at day 6 . The cytokines were subsequently replaced with differentiation medium either on day 8 after an exposure period of 2 days or on day 13 after an exposure period of 7 days. Proteoglycan synthesis was assessed at day 20 and compared with that in controls and with that in cells continuously exposed to cytokines from day 6 to day 20 .

\section{Organ culture}

The middle three metatarsals were aseptically dissected from 2 -day-old neonatal Swiss mice. Bones were cultured at $37^{\circ} \mathrm{C}$ in a humidified atmosphere of $95 \%$ air $/ 5 \% \mathrm{CO}_{2}$ in 24-well plates for a total of 8 days. Each culture well contained $300 \mu l$ of $\alpha$-minimum essential medium (Invitrogen) supplemented with $1 \mathrm{mmol} / \mathrm{l} \beta$-glycerophosphate (Sigma), $0.05 \mathrm{mg} / \mathrm{ml}$ L-ascorbic acid phosphate (Wako Pure Chemicals Ltd, Neuss, Germany), $0.05 \mathrm{mg} / \mathrm{ml}$ gentamycin, $1 \cdot 25 \mu \mathrm{g} / \mathrm{ml}$ fungizone (Invitrogen) and $10 \%$ FBS. TNF $\alpha$, IL-1 $\beta$ and IL-6 (+IL-6R) were added individually and in combination at a final concentration of $10 \mathrm{ng} / \mathrm{ml}$ for the full 8 days. To study spontaneous recovery from cytokine treatment, metatarsals were exposed for the first 2 or 4 days of the 8 -day culture period to TNF $\alpha$ and
IL-1 $\beta$ treatment (individually and in combination); for the remainder of the 8-day culture period the metatarsals were exposed to culture medium only. In all experiments, the medium was changed every second/third day. The influence of resorption on length was studied by adding etidronate at a final concentration of either $10 \mu \mathrm{M}$ or $1 \mu \mathrm{M}$, in combination with IL-1 $\beta \quad(10 \mathrm{ng} / \mathrm{ml})$ for an 8 -day culture period. The experimental protocol was approved by Roslin Institute's Animal Users Committee and the animals were maintained in accordance with Home Office guidelines for the care and use of laboratory animals.

Morphometric analysis Digital images of the metatarsals were captured every second day of culture and viewed on a Nikon Eclipse TE3000 microscope (Nikon, Kingston upon Thames, Surrey, UK), using a digital camera (DS Camera Head DS-5 M; Nikon). The total length of the bone through the centre of the mineralising zone was determined using image analysis software (DS Camera Control Unit DS-L1; Nikon). All results are expressed as a percentage change from harvesting length, which was regarded as baseline.

For the determination of the size (in the direction of longitudinal growth) within the growth region of the distinct chondrocyte maturational zones, the metatarsals were fixed in $70 \%$ ethanol, dehydrated and embedded in paraffin wax (Mushtaq et al. 2004). Sections $(10 \mu \mathrm{m}$ in thickness) were stained with haematoxylin and eosin using standard protocols. The sizes of the proliferating, hypertrophic and mineralising zones of the metatarsals were determined using image analysis software (Nikon).

Cell proliferation and dry weight determination On day 6 of culture $\left[{ }^{3} \mathrm{H}\right]$ thymidine was added (final concentration $10 \mu \mathrm{Ci} / \mathrm{ml}$ ) to each metatarsal for the last $6 \mathrm{~h}$ of culture. After washing in PBS, the metatarsals were extracted in trichloroacetic acid (twice for $30 \mathrm{~min}$ ), acetone (twice for $30 \mathrm{~min}$ ) and ether (three times for $30 \mathrm{~min}$ ) and air dried overnight at room temperature. After the determination of dry weight (Sartorious Micro, Gottingen, Germany) the tissue was solubilised (NCS-II tissue solubiliser; Amersham Biosciences) and the DNA incorporating $\left[{ }^{3} \mathrm{H}\right]$ thymidine was determined using a scintillation counter (Mushtaq et al. 2004). The cell proliferation data are expressed as $\left[{ }^{3} \mathrm{H}\right]$ thymidine (d.p.m.) per metatarsal.

\section{Statistical analysis}

All experiments were performed at least twice. General linear model analysis and the Student's $t$-test were used to assess the data. All data are expressed as the mean \pm S.E.M. of six observations within each experiment. Statistical analysis was performed using Minitab 14 (Minitab Inc, State College, Philadelphia, PA, USA). $P<0.05$ was considered to be significant. 


\section{Results}

Chondrocyte cell culture

Cell proliferation Compared with control cultures, IL- $1 \beta$ reduced cell proliferation, as assessed by $\left[{ }^{3} \mathrm{H}\right]$ thymidine uptake, at every concentration studied (Table 1 ; $P<0 \cdot 001)$. However, TNF $\alpha$ only reduced cell proliferation at the higher concentrations of $100 \mathrm{ng} / \mathrm{ml}$ and $10 \mathrm{ng} / \mathrm{ml}$ (Table $1 ; P<0 \cdot 001$ ). IL-6 did not affect cell proliferation at any of the concentrations studied. No additive or synergistic effects on proliferation were observed when these cytokines were added in combination.

Proteoglycan synthesis Compared with control cultures, IL-1 $\beta$ significantly reduced proteoglycan synthesis, as indicated by Alcian Blue staining at every concentration studied (Table $1 ; P<0 \cdot 001)$. Again, TNF $\alpha$ only reduced proteoglycan synthesis at the higher concentrations of $100 \mathrm{ng} / \mathrm{ml}$ and $10 \mathrm{ng} / \mathrm{ml}$ (Table 1; $P<0 \cdot 001$ ). IL-6 did not significantly alter proteoglycan synthesis at any of the concentrations studied. No additive or synergistic effects on proteoglycan synthesis were observed when these cytokines were added in combination.

Apoptosis Apoptosis, as determined by caspase-3 activity, was significantly increased by exposure to both TNF $\alpha$ (Table 1; $P<0 \cdot 001)$ and IL-1 $\beta$ (Table 1; $P<0 \cdot 01$ ) (both $10 \mathrm{ng} / \mathrm{ml}$ ) compared with control cells. Furthermore, caspase- 3 activity was significantly greater in cells treated with TNF $\alpha$ compared with IL-1 $\beta \quad(P<0 \cdot 001)$. Caspase-3 activity was not significantly increased in cells exposed to IL-6.

Cell number In comparison with control cultures, a significant reduction in cell number, as assessed by cell protein quantification, only occurred following treatment with TNF $\alpha(10 \mathrm{ng} / \mathrm{ml})(P<0 \cdot 01)$. Exposure to IL-1 $\beta$ or IL-6 (both $10 \mathrm{ng} / \mathrm{ml}$ ) did not result in a significant reduction in cell number (Table 1). No additive or synergistic effects on cell number were observed when these cytokines were added in combination.

Chondrogenic gene expression $\mathrm{TNF} \alpha$ and IL-1 $\beta$ $(10 \mathrm{ng} / \mathrm{ml})$ markedly reduced aggrecan, collagen II and collagen X gene expression (Fig. 1). The expression of aggrecan appeared to be particularly decreased by both TNF $\alpha$ and IL- $1 \beta$ treatment. Cells treated with IL- 6 did not show a clear reduction in levels of aggrecan, collagen II and collagen X gene expression.

Recovery Morphological assessment of the ATDC5 cells revealed that exposure to TNF $\alpha(10 \mathrm{ng} / \mathrm{ml})$ induced cell death and detachment from the culture plastic. Hence, none of the recovery periods were associated with a detectable rise in proteoglycan synthesis. Proteoglycan synthesis was not affected following 2 days of exposure to

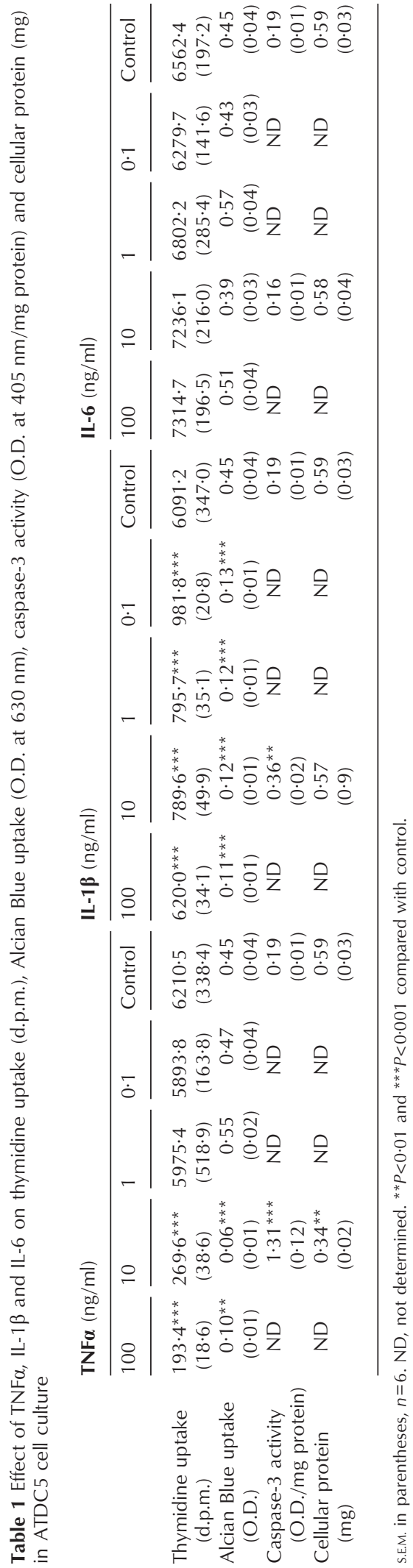

Journal of Endocrinology (2006) 189, 319-328 www.endocrinology-journals.org 


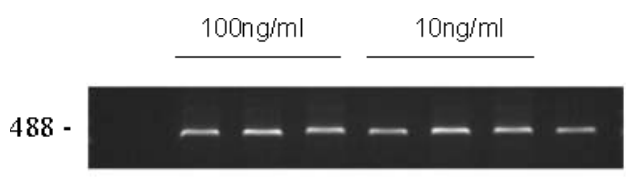

$18 \mathrm{~S}$

B TNF $\alpha$ IL-1, IL-6 TNF $\alpha$ IL-1B IL-6 C

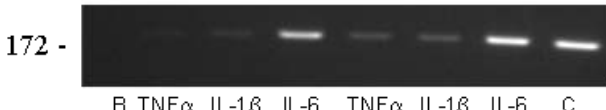

Collagen II

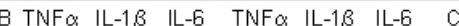

583

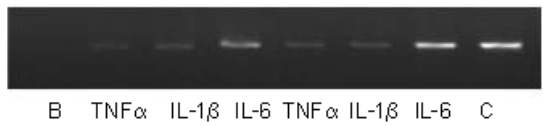

Collagen $X$

$218-$

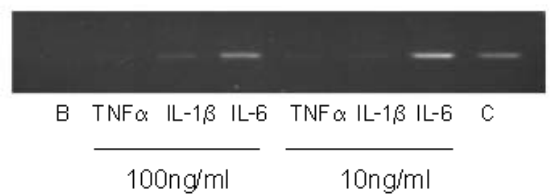

Aggrecan

Figure 1 Semiquantitative RT-PCR analysis of aggrecan, collagen II and collagen $\mathrm{X}$ expression in ATDC 5 cells following exposure to TNF $\alpha, I L-1 \beta$ and IL- 6 at $100 \mathrm{ng} / \mathrm{ml}$ and $10 \mathrm{ng} / \mathrm{ml}$, compared with control (C) samples. B, blank.

IL-1 $\beta$ (Fig. 2). However, by the time the cells were exposed to IL-1 $\beta(10 \mathrm{ng} / \mathrm{ml})$ for 7 days, a $41 \%$ reduction in Alcian Blue staining was evident in comparison with control cells $(P<0 \cdot 001)$. In the cells where 2 days of exposure to IL-1 $\beta(10 \mathrm{ng} / \mathrm{ml})$ was followed by a 12 -day cytokine-free recovery period, proteoglycan synthesis at the end of the 14 days was $12 \%$ less in the treated cells compared with the control $(P<0 \cdot 05)$. This difference in proteoglycan synthesis at the end of 14 days was greater at $38 \%$ when the treatment period was prolonged to 7 days, with a shorter recovery period $(P<0 \cdot 001)$. However, at 14 days, proteoglycan synthesis in these cells which had been treated for 7 days and subsequently had a 7-day recovery period was greater by $16 \%$ when compared with the cells which were continuously treated with IL-1 $\beta$ for 14 days $(P<0 \cdot 05)$.

\section{Neonatal metatarsal organ culture}

Longitudinal growth A reduction in metatarsal growth was first noted after 4 days of exposure to TNF $\alpha$ (38\%; $P<0 \cdot 01)$ and IL-1 $\beta$ (50\%; $P<0 \cdot 001)$ compared with control metatarsals (Fig. 3A). In combination, TNF $\alpha$ and IL- $1 \beta$ reduced metatarsal growth by $66 \%$ of control values after 4 days of exposure $(P<0 \cdot 001)$. At the end of the 8 -day culture period, TNF $\alpha$ reduced growth by $45 \%$ $(P<0 \cdot 01)$ and IL-1 $\beta$ reduced growth by $71 \%(P<0 \cdot 001)$ compared with control metatarsals (Fig. 3A). Treatment with IL-1 $\beta$ with and without TNF $\alpha$ induced shrinking and folding of the metatarsals. In combination, TNF $\alpha$ and IL-1 $\beta$ had an additive effect and reduced metatarsal growth by $110 \%$ of control values $(P<0 \cdot 001)$. By 6 days the combination of TNF $\alpha$ and IL- $1 \beta$ had resulted in an actual reduction of absolute length. Addition of etidronate at $1 \mu \mathrm{M}$ or $10 \mu \mathrm{M}$ did not alter the IL-1 $1 \beta$-induced reduction in metatarsal growth (Fig. 3B). IL-6 did not have any significant effect on metatarsal growth.

Chondrocyte maturational zones TNF $\alpha$ and IL-1 $\beta$ in combination resulted in a significant decrease in the length

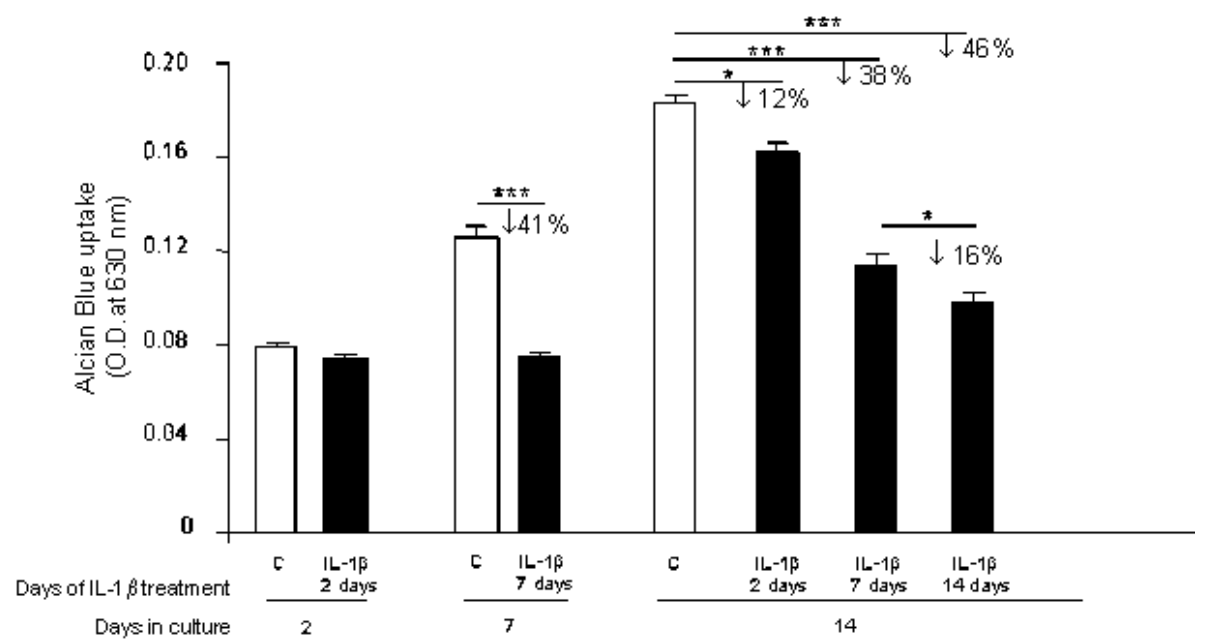

Figure 2 Effect of duration of IL- $1 \beta$ on Alcian Blue uptake (O.D. at $630 \mathrm{~nm}$, means \pm S.E.M., $n=6$ ) in ATDC5 cells. Cells were continuously exposed to IL- $1 \beta$ and assayed at 2,7 and 14 days (IL-1 $\beta$ and control $\square$ ). In addition, cells were exposed to IL-1 $\beta$ for 2 days or 7 days and allowed to recover for 12 or 7 days respectively and were assayed at 14 days. Percentile differences from respective controls are indicated where a significant reduction in Alcian Blue uptake was observed. ${ }^{*} P<0 \cdot 05 ;{ }^{* * *} P<0 \cdot 001$. 

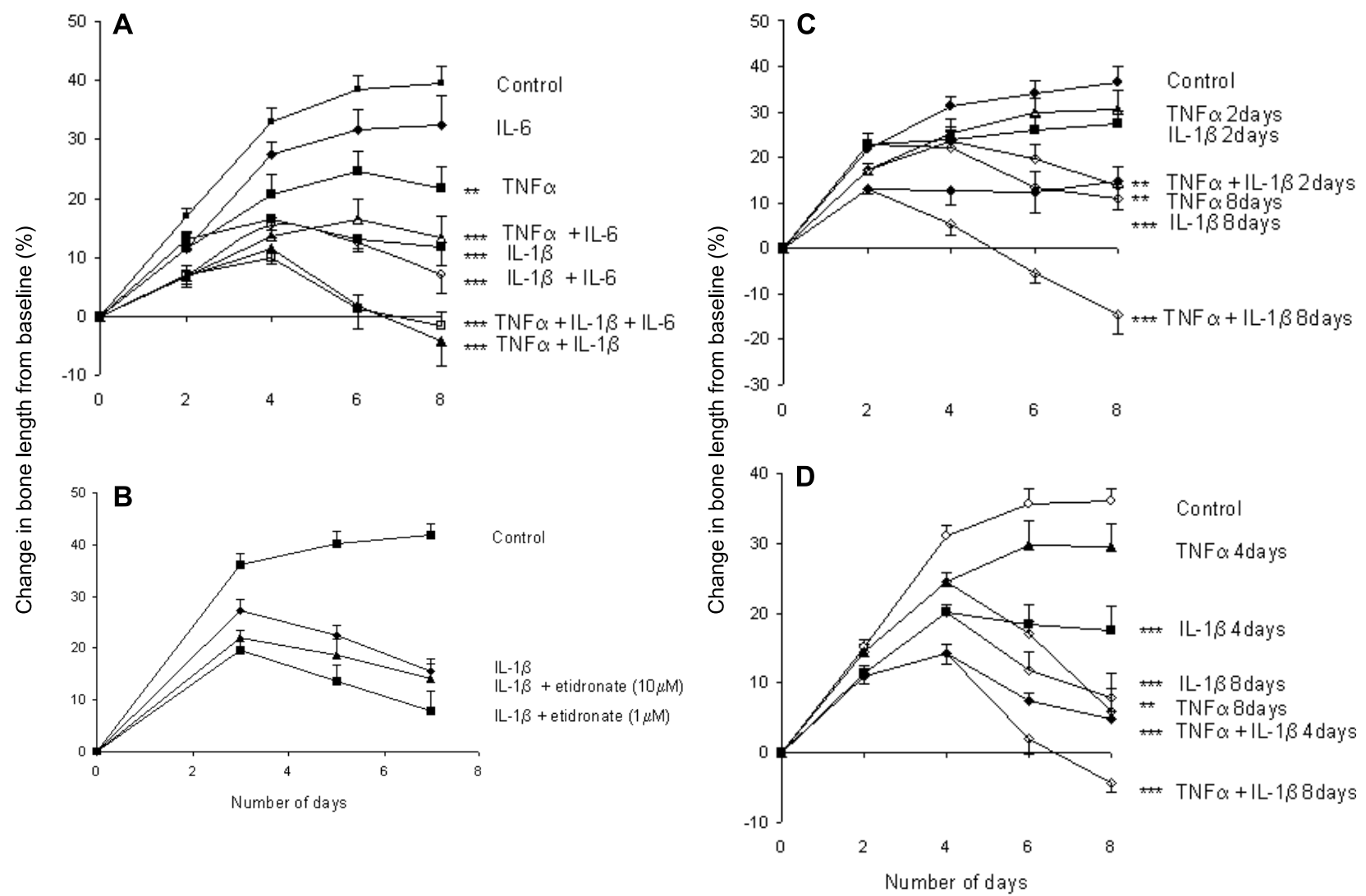

Figure 3 Percentage change in length of postnatal murine metatarsals treated with (A) control medium, IL-6, TNF $\alpha$, TNF $\alpha+I L-6$, IL-1 $\beta$, IL-1 $\beta+I L-6$, TNF $\alpha+I L-1 \beta+I L-6$ and TNF $\alpha+I L-1 \beta$ over an 8 -day period (all $10 \mathrm{ng} / \mathrm{ml})(n=6)$, (B) control medium, IL- $1 \beta(10 \mathrm{ng} / \mathrm{ml})$ and IL-1 $\beta$ +etidronate $(1 \mu \mathrm{M}$ and $10 \mu \mathrm{M})$ over a 7 -day period $(n=4),(C)$ control medium, TNF $\alpha$, IL- $1 \beta$, TNF $\alpha+I L-1 \beta$ (all $10 \mathrm{ng} / \mathrm{ml})$ continuously for 8 days, or for 2 days only, followed by 6 days of cytokine-free recovery $(n=6)$ and (D) control medium, TNF $\alpha$, IL-1 $\beta$, TNF $\alpha+$ IL-1 $\beta$ continuously for 8 days, or for 4 days only, followed by 4 days of cytokine-free recovery. Values are means \pm S.E.M. ${ }^{* \star} P<0 \cdot 01$; ${ }^{* * *} P<0 \cdot 001$ versus control at day 8 .

of the proliferating zone compared with controls $(P<0 \cdot 001)$ (Table 2). The length of the mineralising zone was not altered by any of the cytokine treatments. The hypertrophic zone was significantly reduced compared with controls by TNF $\alpha$, IL $-1 \beta$ and TNF $\alpha+$ IL $-1 \beta$ treatments (Table $2 ; P<0 \cdot 001)$. Furthermore, IL-1 $\beta$ and TNF $\alpha+\mathrm{L}-1 \beta$ reduced the length of the hypertrophic zone more markedly than TNF $\alpha$ alone (Table 2 and Fig. 4; $P<0 \cdot 001$ ).

Cell proliferation and dry weight Compared with control metatarsals, there was a significant reduction in $\left[{ }^{3} \mathrm{H}\right]$ thymidine uptake in metatarsals treated with TNF $\alpha$

Table 2 Effect of TNF $\alpha$, IL-1 $\beta$ and TNF $\alpha+$ IL- $1 \beta$ on metatarsal $\left[{ }^{3} H\right]$ thymidine uptake (d.p.m.), dry weight $(\mu \mathrm{g})$ and lengths of the proliferating, mineralising and hypertrophic zones $(\mu \mathrm{M})$

\begin{tabular}{|c|c|c|c|c|c|}
\hline & $\begin{array}{l}\text { Proliferating } \\
\text { zone } \\
(\mu \mathrm{M})\end{array}$ & $\begin{array}{l}\text { Mineralising } \\
\text { zone } \\
(\mu \mathrm{M})\end{array}$ & $\begin{array}{l}\text { Hypertrophic } \\
\text { zone } \\
(\mu \mathrm{M})\end{array}$ & $\begin{array}{l}{\left[{ }^{3} \mathbf{H}\right] \text { thymidine }} \\
\text { uptake } \\
\text { (d.p.m.) }\end{array}$ & $\begin{array}{l}\text { Dry } \\
\text { weights } \\
(\mu g)\end{array}$ \\
\hline \multicolumn{6}{|l|}{ Treatment } \\
\hline Control & $154(9)$ & $60(8)$ & $60(8)$ & 7977 (1149) & $258(45)$ \\
\hline TNF $\alpha$ & 148 (15) & $61(13)$ & $43(7)^{\star \star \star}$ & $2688(312)^{* * *}$ & $136(20)^{*}$ \\
\hline IL-1 $\beta$ & 143 (16) & $69(8)$ & $8(3)^{* * *}$ & $4273(1171)^{*}$ & $140(21)^{*}$ \\
\hline TNF $\alpha+$ IL-1 $\beta$ & $93(20)^{\star \star \star}$ & $60(8)$ & $12(2)^{\star \star *}$ & $2161(300)^{* * *}$ & $100(12)^{* *}$ \\
\hline
\end{tabular}

S.E.M. in parentheses, $n=6 .{ }^{*} P<0 \cdot 05,{ }^{* *} P<0 \cdot 01$ and ${ }^{* * *} P<0 \cdot 001$ compared with control. 

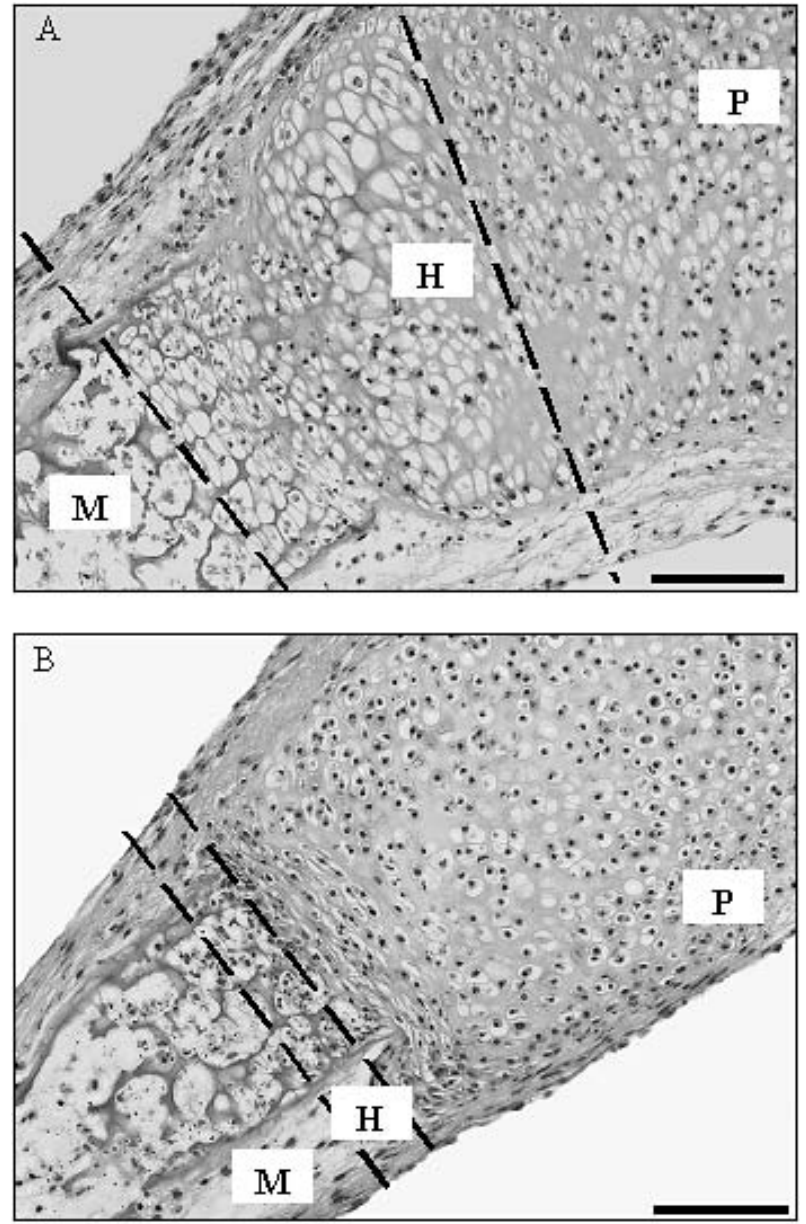

Figure 4 (A) Hypertrophic zone of a control metatarsal and (B) markedly reduced hypertrophic zone following exposure to TNF $\alpha$ and IL-1 $\beta$ in combination. $\mathrm{P}$, proliferative zone; $\mathrm{H}$, hypertrophic zone; $\mathrm{M}$, mineralisation zone. Bar $=100 \mu \mathrm{m}$.

$(P<0 \cdot 001)$, IL-1 $\beta(P<0 \cdot 05)$ and TNF $\alpha+$ IL-1 $\beta(P<0 \cdot 05)$ (Table 2). Metatarsal weight was also significantly reduced compared with controls by TNF $\alpha$, IL-1 $\beta$ (both $P<0 \cdot 05$ ) and TNF $\alpha+$ IL-1 $\beta(P<0 \cdot 01)$ (Table 2$)$.

Recovery Spontaneous recovery over the 8 days of metatarsal growth was assessed by exposing the bones for either 2 days or 4 days to cytokines, followed by a 6-day or a 4-day period of cytokine-free recovery period respectively (Fig. 3C and D). At day 8 , metatarsals that had been exposed to IL-1 $\beta$ or TNF $\alpha$ for the first 2 days had grown a similar amount as the control bones. However, histological analysis revealed that, at the end of the recovery period, the size of the hypertrophic zones of the metatarsals exposed to IL-1 $\beta$ for 2 days remained significantly smaller compared with controls $(P<0 \cdot 001)$ (Table 3). The size of the hypertrophic zones exposed to TNF $\alpha$ for 2 days was not significantly different from
Table 3 Effect of exposure to TNF $\alpha$ and IL-1 $\beta$ ( 2 days) followed by a recovery period ( 6 days) on the lengths of the proliferating, mineralising and hypertrophic zones $(\mu \mathrm{M})$

\begin{tabular}{|c|c|c|c|}
\hline & $\begin{array}{l}\text { Proliferating } \\
\text { zone } \\
(\mu \mathrm{M})\end{array}$ & $\begin{array}{l}\text { Mineralising } \\
\text { zone } \\
(\mu \mathrm{M})\end{array}$ & $\begin{array}{l}\text { Hypertrophic } \\
\text { zone } \\
(\mu \mathrm{M})\end{array}$ \\
\hline \multicolumn{4}{|l|}{ Treatment } \\
\hline Control & $128(8)$ & $62(3)$ & $73(6)$ \\
\hline TNF $\alpha$ recovery & $124(6)$ & $68(2)$ & $67(2)$ \\
\hline IL-1 $\beta$ recovery & $125(12)$ & $69(2)$ & $25(4)^{* * *}$ \\
\hline
\end{tabular}

controls. The percentage change in the length of the metatarsals that had been exposed to a combination of IL-1 $\beta$ and TNF $\alpha$ for 2 days was 59\% less compared with controls $(P<0 \cdot 01)$ by the end of the recovery period, at 8 days (Fig. 3C).

Metatarsals that had been exposed to TNF $\alpha$ only for the first 4 days had grown a similar amount as the control bones after the 4-day recovery period. However, the change in length of metatarsals that were exposed to IL-1 $\beta$ for 4 days followed by 4 days of recovery in the absence of the cytokine was $52 \%$ of controls by the end of the recovery period $(P<0 \cdot 001)$ (Fig. 3D). This lack of recovery was more marked after 4 days of a combination of IL-1 $\beta$ and TNF $\alpha$ where the percentage change in length was $87 \%$ lower than control metatarsals $(P<0 \cdot 001)$.

\section{Discussion}

The current study clearly showed that IL- $1 \beta$ and TNF $\alpha$, but not IL-6, not only have a dramatic, direct effect on chondrocyte dynamics but they also alter the potential for spontaneous recovery. Whilst the mouse metatarsal is a highly physiological model of longitudinal growth (Mushtaq et al. 2004), concerns about the applicability of the fetal model for studying postnatal growth led us to develop a novel, postnatal mouse metatarsal model for studying the local regulation of catch-up growth in conditions associated with postnatal growth retardation. By using this model of longitudinal growth, and combining it with a study of the effect of cytokines on the ATDC5 cell line, we have considerably extended our understanding of the effect of pro-inflammatory cytokines at the level of the growth plate.

In the cell culture studies, we found multiple strands of evidence suggesting that individual pro-inflammatory cytokines have varying effects on growth plate chondrocytes. First, a greater amount of apoptosis occurred following TNF $\alpha$ exposure compared with IL-1 $\beta$ exposure. Although both cytokines reduced proliferation, IL-1 $\beta$ was much more potent, exerting effects at all concentrations examined, whereas TNF $\alpha$ only exerted 
effects at the higher concentrations. Our findings were reinforced by gene expression studies, which showed that TNF $\alpha$ and IL-1 $\beta$ markedly reduced the mRNA expression of aggrecan, collagen II and collagen X. The expression of aggrecan at both the protein and gene level appeared to be particularly sensitive to both TNF $\alpha$ and IL-1 $\beta$ which are reported to stimulate the synthesis of protein-degrading enzymes such as collagenases and stromelysins in cartilage (Reboul et al. 1996, Ohta et al. 1998). Consistent with these observations, we observed a marked reduction in overall proteoglycan synthesis following TNF $\alpha$ and IL-1 $\beta$ exposure. Our previous studies have shown that proteoglycan synthesis is very sensitive to glucocorticoid exposure (Mushtaq et al. 2002). Together with collagen type II, proteoglycans and, in particular, aggrecan, provide a scaffold and stimuli for chondrocyte attachment, migration and differentiation and, thereby, maintain the structural organisation of the growth plate (Bateman et al. 1996). The contribution of aggrecan to bone growth has been demonstrated in a number of murine transgenic models. Cartilage matrix deficiency $(c m d)$ is a result of a $7 \mathrm{bp}$ deletion in exon 5 of the aggrecan gene and results in mice with short limbs (Watanabe et al. 1994). Similarly delayed bone formation and progressive dwarfism have been recorded in mice null for aggrecan link protein (Watanabe \& Yamada 1999). The growth plate cartilage of these mice was characterised by decreased numbers of hypertrophic chondrocytes, which may contribute to the short limbs observed.

Recovery from TNF $\alpha$ exposure in ATDC5 cells could not be studied because of its toxicity to the cells when added during the chondrogenesis period of maturation (Mushtaq et al. 2002). In contrast, exposure to IL-1 $\beta$ was not toxic and allowed detailed studies of the recovery of proteoglycan synthesis. By limiting the duration of exposure to a variable number of days, these studies showed that even a short 2-day period of exposure led to a long-term reduction in proteoglycan synthesis. Although there was some recovery in proteoglycan synthesis after this short period of exposure, this partial recovery was not evident in the cells exposed for longer periods. Interestingly, although there was a long-term reduction in proteoglycan synthesis after the 2-day period of treatment, no differences were observed in proteoglycan synthesis between the treated and control cells at 2 days. This suggests that cytokine-induced effects may manifest themselves at a later stage following cessation of the exposure. A similar phenomenon has also been noted following the removal of glucocorticoid exposure to growth plate chondrocytes (Mushtaq et al. 2002).

The reduction in longitudinal bone growth observed following TNF $\alpha$ and IL-1 $\beta$ treatment of postnatal metatarsals was more marked with the latter cytokine. The initial marked reduction in longitudinal bone growth followed by a reduction in absolute length after a few days of continuous exposure of TNF $\alpha$ and IL-1 $\beta$ in combina- tion was particularly remarkable. The failure to ameliorate these effects with etidronate suggest that it is unlikely that these observed effects were due to cytokine-stimulated osteoclast activity (Manolagas 1995). Our studies showed clear evidence that the growth-inhibitory effects are due to a combination of effects on matrix synthesis, chondrocyte proliferation and a reduction in the hypertrophic zone. Whilst treatment with either TNF $\alpha$ or IL-1 $\beta$ reduced proliferation by comparable amounts, IL-1 $\beta$ seemed to have the predominant effect on the hypertrophic chondrocytes which are the principal determinant of longitudinal bone growth (Noonan et al. 1998).

The metatarsal recovery studies showed that a 2-day exposure to either TNF $\alpha$ or IL-1 $\beta$ alone did not impair subsequent bone growth. However, a 2-day exposure to a combination of these two cytokines reduced subsequent bone growth, demonstrating a synergistic effect of TNF $\alpha$ and IL-1 $\beta$ as reported by Martensson et al. (2004). Our experiments clearly showed that catch-up growth did not occur following combined exposure to TNF $\alpha$ and IL-1 $\beta$ or following a longer, 4-day, period of exposure to IL-1 $\beta$. Four days of exposure to TNF $\alpha$ did not impair subsequent bone growth, indicating that only relatively long-term exposure to TNF $\alpha$ is detrimental to bone growth. In both the ATDC5 and metatarsal recovery studies, however, it is possible that recovery could have occurred given a longer time period of observation.

The results of this study concur with and extend previous reports highlighting the effects of inflammatory cytokines on growth plate chondrocytes. In cultures of rabbit growth plate chondrocytes, IL-1 $\beta$ decreased alkaline phosphatase activity during the hypertrophic stage and suppressed an increase in cell size and type X collagen expression, suggesting an inhibition of chondrocyte terminal differentiation and hypertrophy (Kato et al. 1993). TNFa induced apoptosis in chick growth plate chondrocyte cultures (Aizawa et al. 2001) and suppressed cartilaginous nodule formation and the accumulation of cartilage-specific proteoglycan reduction in the ATDC5 cell line (Horiguchi et al. 2000). Interestingly, Horiguchi et al. (2000) noted that TNFa $(10 \mathrm{ng} / \mathrm{ml})$ increased $\left[{ }^{3} \mathrm{H}\right]$ thymidine uptake in the ATDC5 cell line which is in contrast to our data. This reason for this discrepancy is unclear; however, the reduction in chondrocyte proliferation noted in the ATDC5 cell line was confirmed in the metatarsal model. TNF $\alpha$ has also been shown to synergise with IL-17 to reduce proteoglycan synthesis in fetal mouse metatarsals (van Bezooijen et al. 2002).

In both models reported in our studies IL-6 did not have any significant inhibitory effects. Furthermore, the cell culture studies suggest a possible pro-proliferative effect of IL-6, although this was not a consistent finding. This lack of inhibitory response is also consistent with the findings in another study (Martensson et al. 2004). It is, therefore, possible that IL-6 may mediate growth abnormalities through systemic effects, whereas TNFa and 
IL-1 $\beta$ may act locally at the level of the growth plate. In this postnatal, murine metatarsal model of longitudinal growth, IL-1 $\beta$ and TNF $\alpha$ both had an inhibitory effect on growth at $10 \mathrm{ng} / \mathrm{ml}$. However, in the fetal rat metatarsal model, IL-1 $\beta$ had a positive effect on growth at that concentration and TNF $\alpha$ did not have any effect (Martensson et al. 2004). Our observations not only suggest that the growth-inhibitory effects of TNFa and IL-1 $\beta$ may be mediated through different cellular mechanisms and may be age dependent but they also emphasise the importance of studying more than one model of bone growth.

The partial recovery observed following cytokine exposure is comparable with that reported following cessation of glucocorticoid administration to growth plate chondrocytes (Baron et al. 1992, Mushtaq et al. 2002). Our previous studies have suggested that longitudinal growth and especially chondrocyte hypertrophy in the metatarsal model of growth is highly dependent on insulin-like growth factor-I (IGF-I) action (Mushtaq et al. 2004). It is possible that the growth-inhibitory effects of inflammatory cytokines and glucocorticoids are mediated via similar signalling mechanisms such as the phosphatidylinositol 3-kinase pathway (Kenchappa et al. 2004, Chrysis et al. 2005). Alternatively, cytokines may induce a state of IGF-I resistance by reducing IGF-I signal transduction in chondrocytes by inhibiting insulin receptor substrate- 1 phosphorylation (Broussard et al. 2004) by the up-regulation of the suppressor of cytokine-signalling protein-3 expression (Shi et al. 2004). If this is the case, our experiments indicate that a persistent state of IGF-I resistance may exist following the removal of the insult and this possibility requires further investigation. Our data may also explain the lack of catch-up growth observed in rats administered IGF-I following experimental colitis (Ballinger et al. 2000). In children with juvenile idiopathic arthritis, high-dose treatment with GH leads to a rise in systemic levels of IGF-I and has been reported to reduce the worsening growth retardation but does not seem to result in normalisation of height (Simon et al. 2003). Furthermore, several studies of final height of adults with childhood onset inflammatory bowel disease show that these adults may be relatively short (Castile et al. 1980, Griffiths et al. 1993, Markowtiz et al. 1993, Alemzadeh et al. 2002, Sawczenko et al. 2003). Our data would suggest that even a relatively short period of exposure to pro-inflammatory cytokines, especially when in combination, may have an irreversible effect on growth plate chondrogenesis.

Whilst many previous studies have examined the effects of pro-inflammatory cytokines on articular chondrocytes relatively few have investigated growth plate chondrocytes and none has investigated the potential for spontaneous recovery following exposure. Our results extend the data from previous chondrocyte culture studies and the findings will allow a more focused approach towards studying the mechanisms underlying cytokine-induced growth alterations, as well as investigating the potential benefit of growth-promoting therapy.

\section{Acknowledgements}

We are grateful to Miss Elaine Seawright for her contribution to the experiments.

\section{Funding}

Novo Nordisk UK Ltd and the Biotechnology and Biological Sciences Research Council (BBSRC) generously supported this study. The authors declare that there is no conflict of interest that would prejudice the impartiality of this scientific work.

\section{References}

Aizawa T, Kon T, Einhorn TA \& Gerstenfeld LC 2001 Induction of apoptosis in chondrocytes by tumor necrosis factor-alpha. Journal of Orthopaedic Research 19 785-796.

Alemzadeh N, Rekers-Mombarg LTM, Mearin ML Wit JM, Lamers CB \& van Hogezand RA 2002 Adult height in patients with early onset of Crohn's disease Gut 51 26-29.

Atsumi T, Miwa Y, Kimata K \& Ikawa Y 1990 A chondrogenic cell-line derived from a differentiating culture of AT805 teratocarcinoma cells. Cell Differentiation and Development 30 109-116.

Ballinger AB, Azooz O, El-Hajh T, Poole S \& Farthing MJG 2000 Growth failure occurs through a decrease in insulin-like growth factor 1 which is independent of undernutrition in a rat model of colitis. Gut 46 694-700.

Baron J, Huang Z, Oerter KE, Bacher JD \& Cutler GB 1992 Dexamethasone acts locally to inhibit longitudinal bone-growth in rabbits. American Journal of Physiology 263 E489-E492.

Bateman JF, Lamandé SR \& Ramshaw JAM 1996 Collagen superfamily. In Extracellular Matrix, vol. 2, pp 22-67. Ed WD Comper. Amsterdam, The Netherlands: Harvood Academic Publishers.

Breur GJ, Vanenkevort BA, Farnum CE \& Wilsman NJ 1991 Linear relationship between the volume of hypertrophic chondrocytes and the rate of longitudinal bone-growth growth plates. Journal of Orthopaedic Research 9 348-359.

Broussard SR, McCusker RH, Novakofski JE, Strle K, Shen WH, Johnson RW, Dantzer R \& Kelley KW 2004 IL-1 beta impairs insulin-like growth factor I-induced differentiation and downstream activation signals of the insulin-like growth factor I receptor in myoblasts. Journal of Immunology 172 7713-7720.

Castile RG, Telander RL, Cooney DR, Ilstrup DM, Perrault J, van Heerden J \& Stickler GB 1980 Crohn's disease in children: assessment of the progression of disease, growth and prognosis. Journal of Pediatric Surgery 15 482-469.

Chrysis D, Zaman F, Chagin AS, Takigawa M \& Savendahl L 2005 Dexamethasone induces apoptosis in proliferative chondrocytes through activation of caspases and suppression of the Akt-phosphatidylinositol $3^{\prime}$-kinase signaling pathway. Endocrinology 146 1391-1397.

de Hooge ASK, van de Loo FAJ, Bennink MB, Arntz OJ, Fiselier TJW, Franssen MJAM, Joosten LA, van Lent PL, Richards CD \& 
van den Berg WB 2003 Growth plate damage, a feature of juvenile idiopathic arthritis, can be induced by adenoviral gene transfer of oncostatin M - A comparative study in gene-deficient mice. Arthritis and Rheumatism 48 1750-1761.

Farquarson C 2003 Bone growth. In Biology of Growth of Domestic Animals, pp 170-185. Ed CG Scanes. Ames, IA, USA: Iowa State Press.

Farquharson C, Lester D, Seawright E, Jefferies D \& Houston B 1999 Microtubules are potential regulators of growth-plate chondrocyte differentiation and hypertrophy. Bone 25 405-412.

Farthing MIG, Campbell CA, Walkersmith J, Edwards CRW, Rees LH \& Dawson AM 1981 Nocturnal growth-hormone and gonadotropin-secretion in growth retarded-children with Crohns-disease. Gut 22 933-938.

Goldring SR 2003 Pathogenesis of bone and cartilage destruction in rheumatoid arthritis. Rheumatology 42 (Suppl 2) 11-16.

Griffiths AM, Nguyen P, Smith C MacMillan JH \& Sherman PM 1993 Growth and clinical course of children with Crohn's disease. Gut 34 939-943.

Horiguchi M, Akiyama H, Ito H, Shigeno C \& Nakamura T 2000 Tumour necrosis factor-alpha up-regulates the expression of BMP-4 mRNA but inhibits chondrogenesis in mouse clonal chondrogenic EC cells, ATDC5. Cytokine 12 5296-5301.

Houston B, Seawright E, Jefferies D, Hoogland E, Lester D, Whitehead C \& Farquharson C 1999 Identification and cloning of a novel phosphatase expressed at high levels in differentiating growth plate chondrocytes. Biochimica et Biophysica Acta - Molecular Cell Research 1448 500-506.

Jefferies D, Botman M, Farquharson C, Lester D, Whitehead CC, Thorp BH \& Farquharson C 1998 Cloning differentially regulated genes from chondrocytes using agarose gel differential display. Biochimica et Biophysica Acta - Gene Structure and Expression 1396 237-241.

Jefferies D, Houston B, Lester D, Whitehead CC, Thorp BH, Botman M \& Farquharson C 2000 Expression patterns of chondrocyte genes cloned by differential display in tibial dyschondroplasia. Biochimica et Biophysica Acta - Molecular Basis of Disease 1501 180-188.

Kato Y, Nakashima K, Iwamoto M, Murakami H, Hiranuma H, Koike T, Suzuki F, Fuchihata H, Ikehara Y, Noshiro M et al. 1993 Effects of interleukin-1 on syntheses of alkaline-phosphatase, type-x collagen, and 1,25-dihydroxyvitamin-d(3) receptor, and matrix calcification in rabbit chondrocyte cultures. Journal of Clinical Investigation 92 2323-2330.

Kenchappa P, Yadav A, Singh G, Nandana S \& Banerjee K 2004 Rescue of TNFalpha-inhibited neuronal cells by IGF-1 involves Akt and c-Jun N-terminal kinases. Journal of Neuroscience 76 466-474.

Kirschner BS 1990 Growth and development in chronic inflammatory bowel-disease. Acta Paediatrica Scandanavia 366 98-104.

Kirschner BS, Defavaro MV\& Jensen W 1981 Lactose-malabsorption in children and adolescents with inflammatory bowel-disease. Gastroenterology 81 829-832.

Koedam JA, Hoogerbrugge CM \& Van Buul-Offers SC 2000 Differential regulation of IGF-binding proteins in rabbit costal chondrocytes by IGF-I and dexamethasone. Journal of Endocrinology 165 557-567.

Lowry OH, Rosebrough NJ, Farr AL \& Randall RJ 1951 Protein measurement with the Folin phenol reagent. Joural of Biological Chemistry 193 265-275.

Mainardi GL, Saleri R, Tamanini C \& Baratta M 2002 Effects of interleukin-1-beta, interleukin-6 and tumor necrosis factor-alpha, alone or in association with hexarelin or galanin, on growth hormone gene expression and growth hormone release from pig pituitary cells. Hormone Research 58 180-186.

Manolagas SC 1995 Role of cytokines in bone resorption. Bone 17 (Suppl 2) 63S-67S.

Markowitz J, Grancger K, Rosa J Aiges H \& Daum F 1993 Growth failure in pediatric inflammatory bowel disease. Journal of Pediatric Gastroenterology and Nutrition 16 373-338.

Martensson K, Chrysis D \& Savendahl L 2004 Interleukin-1 beta and TNF-alpha act in synergy to inhibit longitudinal growth in fetal rat metatarsal bones. Journal of Bone and Mineral Research 19 1805-1812.

Mushtaq T \& Ahmed SF 2002 The impact of corticosteroids on growth and bone health. Archives of Disease in Childhood 87 93-96.

Mushtaq T, Farquharson C, Seawright E \& Ahmed SF 2002 Glucocorticoid effects on chondrogenesis, differentiation and apoptosis in the murine ATDC5 chondrocyte cell line. Journal of Endocrinology 175 705-713.

Mushtaq T, Bijman P, Ahmed SF \& Farquharson C 2004 Insulin-like growth factor-I augments chondrocyte hypertrophy and reverses glucocorticoid-mediated growth retardation in fetal mice metatarsal cultures. Endocrinology 145 2478-2486.

Noonan KJ, Hunziker EB, Nessler J \& Buckwalter JA 1998 Changes in cell, matrix compartment, and fibrillar collagen volumes between growth-plate zones. Journal of Orthopaedic Research 16 500-508.

Ohta S, Imai K, Yamashita K, Matsumoto T, Azumano I \& Okada Y 1998 Expression of matrix metalloproteinase 7 (matrilysin) in human osteoarthritic cartilage. Laboratory Investigation 78 79-87.

Reboul P, Pelletier JP, Tardif G, Cloutier JM \& MartelPelletier J 1996 The new collagenase, collagenase- 3 , is expressed and synthesized by human chondrocytes but not by synoviocytes - a role in osteoarthritis. Journal of Clinical Investigation 97 2011-2019.

Robson H, Anderson E, Eden OB, Isaksson O \& Shalet S 1998 Chemotherapeutic agents used in the treatment of childhood malignancies have direct effects on growth plate chondrocyte proliferation. Journal of Endocrinology 157 225-235.

Sawczenko A, Ballinger AB, Croft NM, Sanderson IR \& Savage MO 2003 Adult height in patients with early onset of Crohn's disease. Gut 52 454-455.

Shi H, Tzameli I, Bjorbaek C \& Flier JS 2004 Suppressor of cytokine signaling 3 is a physiological regulator of adipocyte insulin signalling. Journal of Biological Chemistry 279 34733-34740.

Shukunami C, Ishizeki K, Atsumi T, Ohta Y, Suzuki F \& Hiraki Y 1997 Cellular hypertrophy and calcification of embryonal carcinoma-derived chondrogenic cell line ATDC5 in vitro. Journal of Bone and Mineral Research 12 1174-1188.

Simon D, Lucidarme N, Prieur AM, Ruiz JC \& Czernichow P 2003 Effects on growth and body composition of growth hormone treatment in children with juvenile idiopathic arthritis requiring steroid therapy. Journal of Rheumatology 30 2492-2499.

van Bezooijen RL, van der Wee-Pals L, Papapoulos SE \& Lowik CWGM 2002 Interleukin 17 synergises with tumour necrosis factor alpha to induce cartilage destruction in vitro. Annals of the Rheumatic Diseases $61870-876$.

Watanabe H \& Yamada Y 1999 Mice lacking link protein develop dwarfism and craniofacial abnormalities. Nature Genetics $21225-229$.

Watanabe H, Kimata K, Line S, Strong D, Gao LY, Kozak CA \& Yamada Y 1994 Mouse cartilage matrix deficiency $(\mathrm{cmd})$ caused by a 7 bp deletion in the aggrecan gene. Nature Genetics 7 154-157.

Received in final form 20 January 2006

Accepted 31 January 2006 